\title{
Actinomadura malachitica and Microtetraspora viridis Are Synonyms and Should Be Transferred as Actinomadura viridis comb. nov.
}

\author{
SHINJI MIYADOH,* HIROYUKI ANZAI, SHOICHI AMANO, AND TAKASHI SHOMURA \\ Pharmaceutical Research Laboratories, Meiji Seika Kaisha, Ltd., Kohoku-ku, Yokohama 222, Japan
}

\begin{abstract}
We compared strain SF2461, Microtetraspora viridis $\mathrm{JCM} \mathrm{3112}^{\mathrm{T}}$ (T = type strain), Microtetraspora viridis subsp. intermedia $\mathrm{JCM} 3113^{\mathrm{T}}$, and Actinomadura malachitica $\mathrm{JCM} 3297^{\mathrm{T}}$ by using morphological, cultural, physiological, and chemotaxonomic characteristics, as well as deoxyribonucleic acid homology. All of our results indicated that these four strains belong to the same species and that they are far from the other type strains of Microtetraspora species. Therefore, we propose that Actinomadura malachitica is a synonym of Microtetraspora viridis and that Microtetraspora viridis should be transferred to the genus Actinomadura as Actinomadura viridis comb. nov., with strain JCM 3112 (= ATCC 27103) as the type strain.
\end{abstract}

During classification studies of an actinomycete designated strain SF2461, which bore greenish aerial masses, we found that this organism was closely related to the descriptions of Microtetraspora viridis and Actinomadura malachitica. The name Microtetraspora viridis was proposed by Nonomura and Ohara in 1971 (16). Independently in 1972, Lavrova et al. (8) published the name A. malachitica. Both of these names are valid and appear on the Approved Lists of Bacterial Names (22). It has recently been recognized by some researchers $(1,4,5,19)$ that the genus Actinomadura is heterogeneous, and this taxon has therefore been divided into two aggregate groups (group 1, the Actinomadura madurae-A. malachitica-Actinomadura citrea group, and group 2, the Actinomadura pusilla-Actinomadura ferruginea group). Also, certain species of Microbispora, Microtetraspora, and Nocardiopsis have been transferred to the genus Actinomadura. Lechevalier et al. (11), who studied phospholipid compositions, proposed that all Actinomadura-like organisms with a type PI phospholipid should be placed in the genus Actinomadura and that those organisms with a type PIV phospholipid should be placed in the genus $\mathrm{Mi}$ crotetraspora. Chemotaxonomic and deoxyribonucleic acid (DNA) data for sporoactinomycetes with wall chemotype III have not always coincided with the classification system established by using traditional phenotypic characters, especially morphology. We compared strain SF2461 with $A$. malachitica $\mathrm{JCM} 3297^{\mathrm{T}}(\mathrm{T}=$ type strain), Microtetraspora viridis $\mathrm{JCM} 3112^{\mathrm{T}}$, and Microtetraspora viridis subsp. intermedia JCM $3113^{\mathrm{T}}$ by using various criteria, including DNADNA hybridization, in order to clarify the taxonomic relationships of these organisms. In addition, we studied the taxonomic status of the genus Microtetraspora Thiemann et al. (24) by using the type strains of species belonging to the genus Microtetraspora and related genera.

\section{MATERIALS AND METHODS}

Bacterial strains. Strain SF2461 was isolated in February 1985 in our laboratory by the dry heating method developed by Nonomura and Ohara (15). The soil sample which we used was collected in Yokohama, Japan. The type strains used in this study are listed in Table 1 . These strains were

\footnotetext{
* Corresponding author.
}

obtained from the Japan Collection of Microorganisms, Saitama, Japan, the Institute for Fermentation, Osaka, Japan, and the American Type Culture Collection, Rockville, Md. The abbreviations used for genus names in Fig. 3 are those proposed by Rogosa et al. (20).

Morphological, cultural, and physiological characteristics. The methods which we used were generally similar to those described previously $(13,14)$. Briefly, methods adopted by the International Streptomyces Project (21) were used for taxonomic characterization and the carbohydrate utilization studies. Cultural and physiological characteristics were determined by using the methods of the International Streptomyces Project and of Waksman (26). Observations were made after incubation at $28^{\circ} \mathrm{C}$ for 2 to 4 weeks. Color determinations were made by comparing the cultures with color chips from the Color Harmony Manual, 4th ed. (7). For scanning electron microscopy, a spore-bearing agar block (diameter, $4 \mathrm{~mm}$ ) was fixed in osmium tetroxide fumes overnight, frozen in liquid nitrogen, and then freeze-dried. Each specimen was coated with gold-palladium by using an

TABLE 1. Strains used in this study

\begin{tabular}{|c|c|}
\hline Species or subspecies & Strain designation \\
\hline \multicolumn{2}{|l|}{ Our isolates } \\
\hline "Actinomadura viridis" & SF2461 (= IFO 14771) \\
\hline Actinomadura atramentaria. & $\mathrm{SF} 2197^{\mathrm{T}}\left(=\mathrm{JCM} 6250^{\mathrm{T}}\right)$ \\
\hline Microbispora viridis ........... & $\mathrm{SF} 2240^{\mathrm{T}}\left(=\mathrm{IFO} 14328^{\mathrm{T}}\right)$ \\
\hline \multicolumn{2}{|l|}{ Type strains } \\
\hline Actinomadura citrea ... & ATCC $27887^{\mathrm{T}}$ \\
\hline Actinomadura ferruginea.. & $\mathrm{JCM} 3283^{\mathrm{T}}$ \\
\hline Actinomadura helvata ..... & $\mathrm{JCM} 3143^{\mathrm{T}}$ \\
\hline Actinomadura macra ....... & ATCC $31286^{\mathrm{T}}$ \\
\hline Actinomadura malachitica.. & $\mathrm{JCM} 3297^{\mathrm{T}}$ \\
\hline Actinomadura pusilla .................. & ATCC $27296^{\mathrm{T}}$ \\
\hline Actinomadura verrucosospora ...... & $\mathrm{JCM} 3147^{\mathrm{T}}$ \\
\hline Microbispora rosea ....................... & $\mathrm{JCM} 3006^{\mathrm{T}}$ \\
\hline Microtetraspora glauca .................. & $\mathrm{JCM} 3300^{\mathrm{T}}$ \\
\hline Microtetraspora fusca.... & ATCC $23058^{\mathrm{T}}$ \\
\hline Microtetraspora niveoalba ... & JCM $3149^{\mathrm{T}}$ \\
\hline Microtetraspora viridis ................ & $\mathrm{JCM} 3112^{\mathrm{T}}$ \\
\hline \multicolumn{2}{|l|}{ Microtetraspora viridis subsp. } \\
\hline 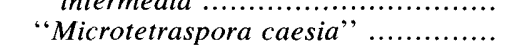 & ATCC $31295^{\mathrm{T}}$ \\
\hline Streptosporangium roseum ............. & IFO $3776^{\mathrm{T}}$ \\
\hline Streptomyces griseus ........................ & IFO $12875^{\mathrm{T}}$ \\
\hline
\end{tabular}


TABLE 2. Morphological, cultural, and chemotaxonomic characteristics of strain SF2461 and related strains ${ }^{a}$

\begin{tabular}{|c|c|c|c|c|c|c|c|c|c|c|c|c|}
\hline \multirow{2}{*}{ Strain } & \multirow{2}{*}{$\begin{array}{l}\text { Aerial } \\
\text { mass } \\
\text { color }\end{array}$} & \multicolumn{2}{|c|}{$\begin{array}{l}\text { Spore chain } \\
\text { morphology }^{b}\end{array}$} & \multirow{2}{*}{$\begin{array}{c}\text { Spore } \\
\text { surfaces }\end{array}$} & \multirow{2}{*}{$\begin{array}{c}\text { Fragmen- } \\
\text { tation } \\
\text { of } \\
\text { mycelia }^{c}\end{array}$} & \multirow{2}{*}{$\begin{array}{l}\text { Wall } \\
\text { chemo- } \\
\text { type }\end{array}$} & \multirow{2}{*}{$\begin{array}{l}\text { Guanine- } \\
\text { plus- } \\
\text { cytosine } \\
\text { content } \\
\text { (mol\%) }\end{array}$} & \multirow{2}{*}{$\begin{array}{l}\text { Phospho- } \\
\text { lipid } \\
\text { type }\end{array}$} & \multicolumn{4}{|c|}{ Menaquinone composition (\%) } \\
\hline & & $\begin{array}{l}\text { Four } \\
\text { spores }\end{array}$ & $\begin{array}{l}\text { Long } \\
\text { straight } \\
\text { chains }\end{array}$ & & & & & & $\begin{array}{c}\text { MK-9 } \\
\left(\mathrm{H}_{2}\right)\end{array}$ & $\begin{array}{c}\text { MK-9 } \\
\left(\mathrm{H}_{4}\right)\end{array}$ & $\begin{array}{c}\text { MK-9 } \\
\left(\mathbf{H}_{6}\right)\end{array}$ & $\begin{array}{l}\text { MK-9 } \\
\left(\mathrm{H}_{8}\right)\end{array}$ \\
\hline SF2461 & $\begin{array}{c}\text { Green } \\
(22 \mathrm{ec}-24 \mathrm{ge})\end{array}$ & + & + & Smooth & - & IIIB & 72 & PI & 2 & 9 & 60 & 29 \\
\hline A. malachitica JCM $3297^{\mathrm{T}}$ & $\begin{array}{c}\text { Green } \\
(24 \mathrm{ec}-24 \mathrm{ge})\end{array}$ & + & + & Smooth & + & IIIB & 72 & PI & 2 & 20 & 56 & 22 \\
\hline $\begin{array}{l}\text { Microtetraspora viridis } \mathrm{JCM} \\
3112^{\mathrm{T}}\end{array}$ & $\begin{array}{l}\text { Green } \\
(24 \mathrm{ec})\end{array}$ & + & - & Smooth & - & IIIB & 72 & PI & 1 & 12 & 60 & 27 \\
\hline $\begin{array}{l}\text { Microtetraspora viridis subsp. } \\
\text { intermedia } \mathrm{JCM} 3113^{\mathrm{T}}\end{array}$ & $\begin{array}{c}\text { Green } \\
\text { (24ec-24ig) }\end{array}$ & + & + & Smooth & - & IIIB & 72 & PI & 6 & 32 & 51 & 8 \\
\hline
\end{tabular}

${ }^{a}$ For fatty acid compositions see Table 5 .

${ }^{b}$ Strains SF2461, JCM $3297^{\mathrm{T}}$, and JCM $3113^{\mathrm{T}}$ had two types of spore chains, as shown in Fig. 1A.

${ }^{c}$ Fragmentation of vegetative mycelia was observed under submerged growth conditions.

ion sputter instrument (model JFC-1100; Japan Electron Optics Laboratory Co., Ltd., Tokyo, Japan) and was then observed with an electron microscope (model JEM 100CASID; Japan Electron Optics Laboratory Co., Ltd.).

Chemical analysis of cells. The presence and form of diaminopimelic acid and the presence of sugars in purified cell wall and whole-cell hydrolysates were determined by the methods of Becker et al. (2) and Lechevalier (9). Phospholipids were analyzed by the procedure of Lechevalier et al. $(10,11)$. Menaquinone samples were prepared by extraction with chloroform-methanol (2:1) from dried cells and subsequent purification by thin-layer chromatography. They were analyzed by using a mass spectrometer (model M-80B; Hitachi, Ltd., Tokyo, Japan) and by high-performance liquid chromatography (model LC-6A; Shimadzu Corp., Kyoto, Japan) $(3,23)$. The compositions of the methyl esters of cellular fatty acids (18) were determined by gas chromatography (model HP-5880A; Hewlett-Packard Co., Avondale, $\mathrm{Pa}$.), using SPB-1 and Supelcowax 10 capillary columns with a bacterial fatty acid methyl ester mixture (type 4-7080; Supelco, Inc., Bellefonte, $\mathrm{Pa}$.) as the standard. The guanineplus-cytosine contents of the DNAs were calculated from their thermal denaturation temperatures (12) by spectrophotometry (model Response TM; Gilford Instrument Laboratories, Inc., Oberlin, Ohio) in $0.1 \times$ SSC $(1 \times$ SSC is $0.15 \mathrm{M}$ $\mathrm{NaCl}$ plus $0.015 \mathrm{M}$ sodium citrate, $\mathrm{pH} 7.0$ ), using DNA from Micrococcus luteus JCM $1464^{\mathrm{T}}$ as the standard (72 mol\%).

Preparation of DNA. Cells for DNA studies were grown in YD broth (1\% yeast extract, $1 \%$ glucose, $\mathrm{pH} 7.0)$ on a rotary shaker $(220 \mathrm{rpm})$ at $28^{\circ} \mathrm{C}$ for 2 to 3 days, harvested by centrifugation, and washed with distilled water. The frozen cells were then ground into fine powder under liquid nitrogen by using a blender (model Homogenizer AM-3; Nihon Seiki Kaisha, Ltd., Tokyo, Japan) and suspended in TES [0.2 M tris(hydroxymethyl)aminomethane hydrochloride, $0.02 \mathrm{M}$ ethylenediaminetetraacetic acid, $0.05 \mathrm{M} \mathrm{NaCl}, \mathrm{pH}$ 8.0] containing $1 \%$ sodium dodecyl sulfate at $40^{\circ} \mathrm{C}$. The total DNA was extracted twice with phenol saturated with TES, precipitated with 2 volumes of ethanol, and then spooled with a glass rod. The total DNA was dissolved in $0.05 \times$ TES and then treated with ribonuclease A (Sigma Chemical Co., St. Louis, Mo.) and pronase K (Kaken Seiyaku Co. Ltd., Tokyo, Japan) according to the directions of the suppliers. When this procedure was used, DNA fragments that were 5

TABLE 3. Physiological characteristics of strain SF2461 and related strains

\begin{tabular}{|c|c|c|c|c|}
\hline Characteristic & $\begin{array}{l}\text { Strain } \\
\text { SF2461 }\end{array}$ & $\begin{array}{l}\text { A. malachitica } \\
\text { JCM } 3297^{\mathrm{T}}\end{array}$ & $\begin{array}{c}\text { Microtetraspora } \\
\text { viridis } \\
\mathrm{JCM} 3112^{\mathrm{T}}\end{array}$ & $\begin{array}{l}\text { Microtetraspora viridis } \\
\text { subsp. intermedia } \\
\text { JCM } 3113^{\mathrm{T}}\end{array}$ \\
\hline Liquefaction of gelatin & $+^{a}$ & - & + & + \\
\hline Hydrolysis of starch & + & - & + & + \\
\hline Reduction of nitrate & - & - & - & - \\
\hline Peptonization of milk & + & + & + & + \\
\hline Coagulation of milk & - & - & - & - \\
\hline Growth at $42^{\circ} \mathrm{C}$ & + & + & + & + \\
\hline $5 \% \mathrm{NaCl}$ tolerance & + & + & + & + \\
\hline Formation of melanoid pigment & - & - & - & - \\
\hline \multicolumn{5}{|l|}{ Utilization of: } \\
\hline D-Glucose & + & + & + & + \\
\hline Glycerol & $(+)$ & $(+)$ & $(+)$ & $(+)$ \\
\hline D-Fructose & $(+)$ & $(+)$ & $(+)$ & $(+)$ \\
\hline D-Xylose & $(+)$ & $(+)$ & $(+)$ & $(+)$ \\
\hline L-Arabinose & $(+)$ & $(+)$ & $(+)$ & $(+)$ \\
\hline D-Mannitol & + & + & + & + \\
\hline myo-Inositol & - & - & - & - \\
\hline L-Rhamnose & + & + & + & + \\
\hline Raffinose & - & - & - & - \\
\hline Sucrose & $(+)$ & $(+)$ & $(+)$ & $(+)$ \\
\hline
\end{tabular}

${ }^{a}+$, Positive; (+), weakly positive; - , negative. 
TABLE 4. DNA homologies of strain SF2461 and related strains

\begin{tabular}{|c|c|c|c|c|}
\hline \multirow[b]{2}{*}{ Source of unlabeled DNA } & \multicolumn{4}{|c|}{$\%$ Hybridization with ${ }^{32}$ P-labeled DNA from: } \\
\hline & $\begin{array}{l}\text { Strain } \\
\text { SF2461 }\end{array}$ & $\begin{array}{l}\text { A. malachitica } \\
\text { JCM } 3297^{\mathrm{T}}\end{array}$ & $\begin{array}{c}\text { Microtetraspora } \\
\text { viridis } \\
\mathrm{JCM} 3112^{\mathrm{T}}\end{array}$ & $\begin{array}{l}\text { Microtetraspora viridis } \\
\text { subsp. intermedia } \\
\text { JCM } 3113^{\mathrm{T}}\end{array}$ \\
\hline Strain SF2461 & 100 & 72 & 71 & 69 \\
\hline A. malachitica JCM $3297^{\mathrm{T}}$ & 69 & 100 & 59 & 58 \\
\hline Microtetraspora viridis $\mathrm{JCM} 3112^{\mathrm{T}}$ & 81 & 68 & 100 & 93 \\
\hline $\begin{array}{l}\text { Microtetraspora viridis subsp. intermedia } \\
\text { JCM } 3113^{\mathrm{T}}\end{array}$ & 84 & 71 & 96 & 100 \\
\hline Actinomadura citrea ATCC $27887^{\mathrm{T}}$ & 16 & 20 & 16 & 17 \\
\hline Actinomadura verrucosospora JCM $3147^{\mathrm{T}}$ & 18 & 18 & 17 & 16 \\
\hline Actinomadura atramentaria $\mathrm{SF} 2197^{\mathrm{T}}$ & 20 & 22 & 23 & 22 \\
\hline Microbispora viridis $\mathrm{SF} 2240^{\mathrm{T} a}$ & 15 & 17 & 16 & 15 \\
\hline Microtetraspora glauca JCM $3300^{\mathrm{T}}$ & 7 & 9 & 7 & 8 \\
\hline Microtetraspora fusca ATCC $23058^{\mathrm{T}}$ & 8 & 9 & 9 & 8 \\
\hline Microtetraspora niveoalba JCM $3149^{\mathrm{T}}$ & 8 & 7 & 6 & 6 \\
\hline "Microtetraspora caesia" ATCC $31295^{\mathrm{T}}$ & 11 & 12 & 9 & 10 \\
\hline Microbispora rosea $\mathrm{JCM} 3006^{\mathrm{T}}$ & 9 & 10 & 7 & 7 \\
\hline Streptomyces griseus IFO $12875^{\mathrm{T}}$ & 6 & 7 & 5 & 6 \\
\hline
\end{tabular}

${ }^{a}$ We are planning to propose the transfer of Microbispora viridis to the genus Actinomadura.

to 23 kilobase pairs long or longer were obtained, as measured by $0.8 \%$ agarose gel electrophoresis, using fragments of $\lambda$ phage DNA digested with HindIII as the standard.

DNA-DNA hybridizations. The methods used for DNADNA hybridization were generally the same as those described by Hopwood et al. (6). DNA probes (100 ng of purified DNA per labeling reaction) were radiolabeled with 20 to $30 \mu \mathrm{Ci}$ of deoxycytidine $\left[\alpha-{ }^{32} \mathrm{P}\right]$ triphosphate (type 33004X; ICN Radiochemicals, Irvine, Calif.) by using a multiprime DNA labeling kit (type RPN 1601Y; Amersham International plc., Amersham, United Kingdom) and the rapid protocol. Hybridizations were carried out on nylon membranes (type Hybond-N RPN 1732N; Amersham International plc.) by using the dot blotting protocol of the supplier. Unlabeled target DNAs $(0.6 \mu \mathrm{g})$ were spotted onto a membrane in triplicate, denatured by using $1.5 \mathrm{M} \mathrm{NaCl}-0.5$
$\mathrm{N} \mathrm{NaOH}$, neutralized with $1.5 \mathrm{M} \mathrm{NaCl}-0.5 \mathrm{M}$ tris(hydroxymethyl)aminomethane hydrochloride- $0.001 \mathrm{M}$ ethylenediaminetetraacetic acid ( $\mathrm{pH} 7.5)$, and then fixed to the membrane by using an ultraviolet transilluminator. The reassociation reaction between the membrane-fixed DNA and $50 \mathrm{ng}$ of heat-denatured $\left[{ }^{32} \mathrm{P}\right] \mathrm{DNA}$ was performed with 8 to $12 \mathrm{ml}$ of hybridization solution $(3 \times \mathrm{SSC}-0.1 \%$ sodium dodecyl sulfate containing denatured nonhomologous DNA from calf thymus at a final concentration of $100 \mu \mathrm{g} / \mathrm{ml}$ and $4 \times$ Denhardt solution) within a plastic bag at $70^{\circ} \mathrm{C}$ for 16 to $20 \mathrm{~h}$. After hybridization, the membranes were washed once in $2 \times$ $\mathrm{SSC}-0.1 \%$ sodium dodecyl sulfate at $70^{\circ} \mathrm{C}$ for $1 \mathrm{~h}$. These membranes were air-dried, exposed to X-ray film at $-80^{\circ} \mathrm{C}$ overnight, and then cut into individual dots in order to measure the radioactivity by using a liquid scintillation counter (model LS-5800; Beckman Instruments, Inc., Ful-

TABLE 5. Fatty acid compositions of the strains tested

\begin{tabular}{|c|c|c|c|c|c|c|c|c|c|c|c|c|}
\hline \multirow{2}{*}{ Organism } & \multicolumn{12}{|c|}{ Fatty acid composition $(\%)^{a}$} \\
\hline & 14:0 & 15:0 & $16: 0$ & 17:0 & 18:0 & $\mathrm{i}-15$ & $\mathrm{i}-16$ & $\mathrm{a}-17$ & $10 \mathrm{M} 17$ & $10 \mathrm{M} 18$ & $16: 1$ & $18: 1$ \\
\hline Strain SF2461 & 2 & & 26 & 1 & 16 & & 4 & & & 14 & 3 & 32 \\
\hline A. malachitica JCM $3297^{\mathrm{T}}$ & 1 & & 25 & 2 & 7 & & 8 & & & 20 & 5 & 29 \\
\hline Microtetraspora viridis $\mathrm{JCM} 3112^{\mathrm{T}}$ & 1 & & 24 & 1 & 12 & & 5 & & & 13 & 6 & 36 \\
\hline $\begin{array}{l}\text { Microtetraspora viridis subsp. intermedia } \\
\text { JCM } 3113^{\mathrm{T}}\end{array}$ & 1 & & 24 & 1 & 10 & & 3 & & & 18 & 6 & 35 \\
\hline Actinomadura verrucospora JCM $3147^{\mathrm{T}}$ & 1 & & 35 & 1 & 7 & & 3 & & & 24 & 5 & 22 \\
\hline Actinomadura citrea ATCC $27887^{\mathrm{T}}$ & 1 & & 36 & & 6 & & 3 & & & 24 & 4 & 25 \\
\hline Actinomadura macra ATCC $31286^{\mathrm{T}}$ & 2 & 1 & 38 & 2 & 5 & & 2 & 1 & 1 & 26 & 4 & 15 \\
\hline Actinomadura atramentaria $\mathrm{SF} 2197^{\mathrm{T}}$ & 1 & 3 & 17 & 4 & 2 & & 6 & 4 & 8 & 39 & 2 & 7 \\
\hline Actinomadura pusilla ATCC $27296^{\mathrm{T}}$ & 1 & 5 & 4 & 4 & 1 & 4 & 21 & 10 & 24 & 4 & 3 & 4 \\
\hline Actinomadura helvata JCM $3143^{\mathrm{T}}$ & 2 & 4 & 17 & 4 & 1 & 4 & 19 & 11 & 8 & 2 & 8 & 5 \\
\hline Microbispora rosea $\mathrm{JCM} 3006^{\mathrm{T}}$ & & 2 & 10 & 9 & 3 & 2 & 41 & 8 & 12 & 1 & 3 & 3 \\
\hline Microtetraspora glauca JCM $3300^{\mathrm{T}}$ & 1 & 6 & 14 & 9 & 3 & 4 & 23 & 9 & 13 & 3 & 3 & 3 \\
\hline Microtetraspora fusca ATCC $23058^{\mathrm{T}}$ & 1 & 3 & 2 & 3 & 2 & 1 & 38 & 9 & 19 & 2 & 3 & 6 \\
\hline Microtetraspora niveoalba JCM $3149^{\mathrm{T}}$ & & 1 & 2 & 1 & 9 & 3 & 45 & 11 & 8 & 1 & 1 & 8 \\
\hline "Microtetraspora caesia" ATCC $31295^{\mathrm{T}}$ & & 2 & 2 & 3 & & 8 & 15 & 40 & 1 & & 4 & 3 \\
\hline
\end{tabular}

a Fatty acid abbreviations are exemplified by the following: i-16, 14-methylpentadecanoic acid; 14:0, tetradecanoic acid; a-17, 14-methylhexadecanoic acid 16:1, hexadecenoic acid; 10M18, 10-methyloctadecanoic acid. The columns and conditions used for gas chromatography were as follows: for the SPB-1 fused silica capillary column $\left(30 \mathrm{~m}\right.$ by $0.53 \mathrm{~mm}$ [inside diameter]), the column temperature was held for $4 \mathrm{~min}$ at $150^{\circ} \mathrm{C}$ and then increased to $250^{\circ} \mathrm{C}$ at a rate of $4{ }^{\circ} \mathrm{C} / \mathrm{min}$, the injection temperature was $250^{\circ} \mathrm{C}$, and the detector temperature was $280^{\circ} \mathrm{C}$; for the Supelcowax-10 fused silica capillary column $(30 \mathrm{~m}$ by $0.53 \mathrm{~mm}$ [inside diameter]), the column temperature was $160^{\circ} \mathrm{C}$, the injection temperature was $200^{\circ} \mathrm{C}$, and the detector temperature was $250^{\circ} \mathrm{C}$. The detector was a flame ionization detector. The carrier gas was helium ( 30 to $40 \mathrm{ml} / \mathrm{min}$ ). 


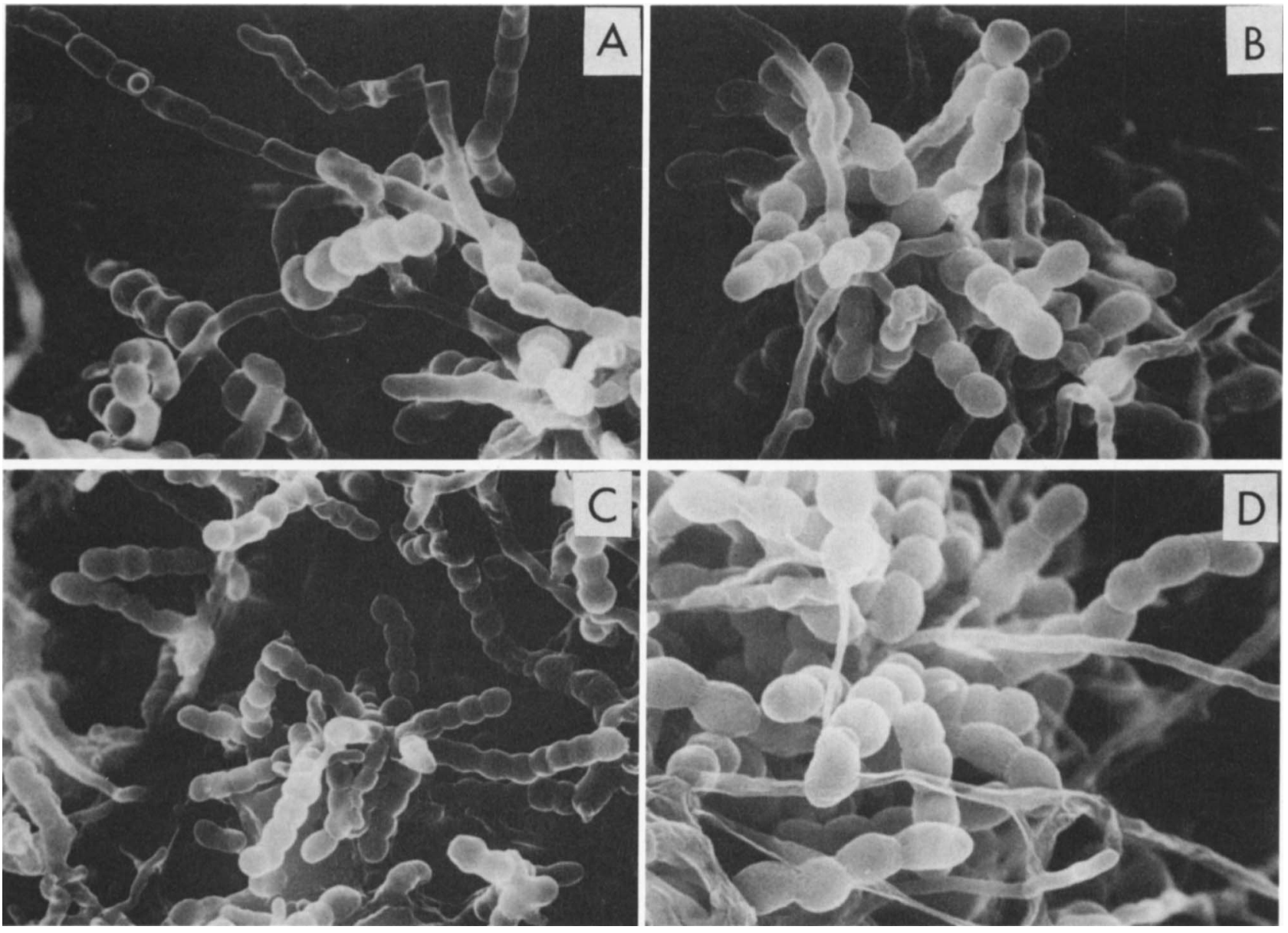

FIG. 1. Scanning electron micrographs of strain SF2461 and related strains. (A) Strain SF2461. Note the two types of spore chain morphology. Magnification, $\times 6,000$. (B) A. malachitica $\mathrm{JCM} 3297^{\mathrm{T}}$. Magnification, $\times 6,000$. (C) Microtetraspora viridis $\mathrm{JCM}^{3112^{\mathrm{T}}}$ Magnification, $\times 4,000$. (D) Microtetraspora viridis subsp. intermedia $\mathrm{JCM} 3113^{\mathrm{T}}$. Magnification, $\times 6,000$.
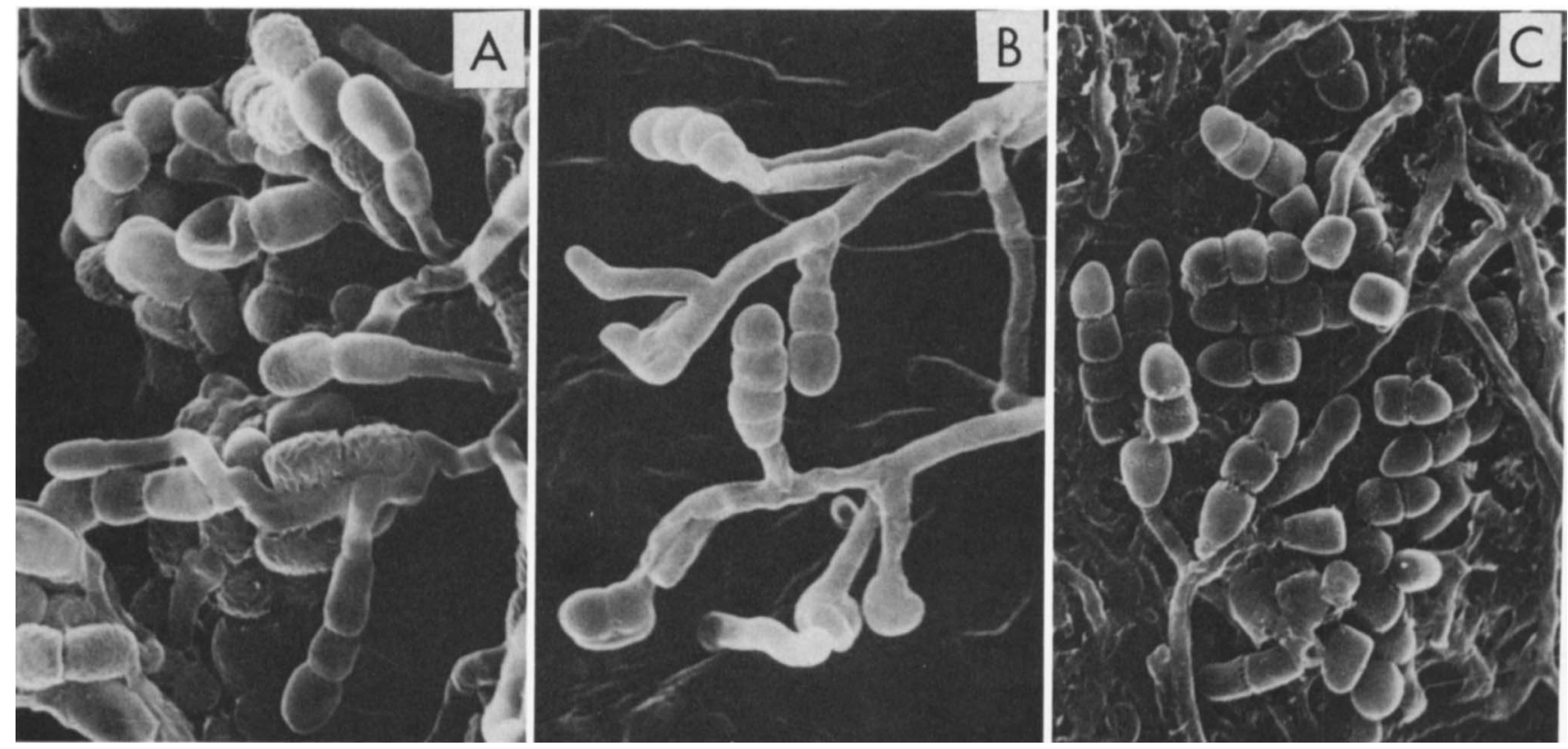

FIG. 2. Scanning electron micrographs of type strains of Microtetraspora species. (A) Microtetraspora glauca JCM $3300^{\mathrm{T}}$. Magnification, $\times 6,000$. (B) Microtetraspora fusca ATCC 23058 ${ }^{\mathrm{T}}$. Magnification, $\times 5,000$. (C) Microtetraspora niveoalba JCM 3149 ${ }^{\mathrm{T}}$. Magnification, $\times 4,000$. 


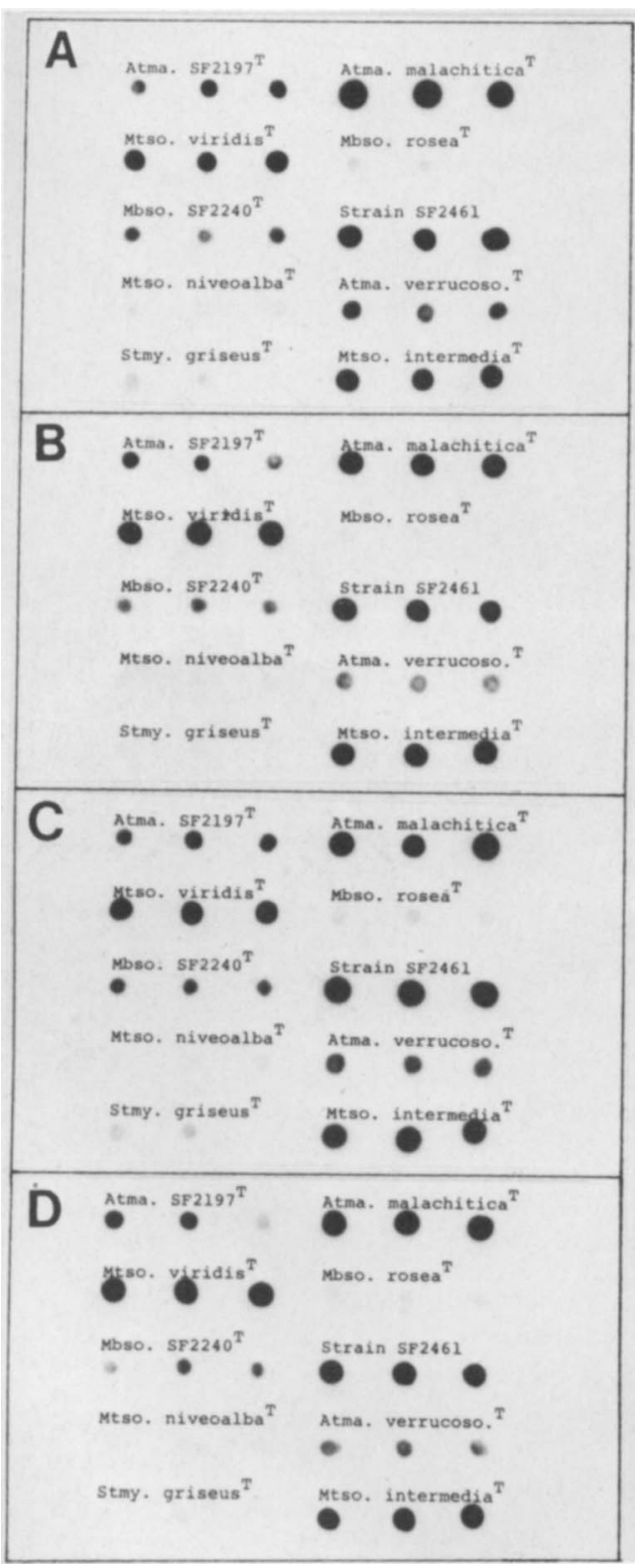

FIG. 3. Typical autoradiography of DNA-DNA dot hybridization of strain SF2461 and related strains. As indicated on the figure, target DNAs were spotted in triplicate in the following order: Actinomadura atramentaria SF2197 ${ }^{\mathrm{T}}$, A. malachitica $\mathrm{JCM} 3297^{\mathrm{T}}$ Microtetraspora viridis $\mathrm{JCM} 3112^{\mathrm{T}}$, Microbispora rosea $\mathrm{JCM} 3006^{\mathrm{T}}$, Microbispora viridis SF2240 ${ }^{\mathrm{T}}$, strain SF2461, Microtetraspora niveoalba $\mathrm{JCM} 3149^{\mathrm{T}}$, Actinomadura verrucosospora $\mathrm{JCM} 3147^{\mathrm{T}}$, Streptomyces griseus IFO $12875^{\mathrm{T}}$, and Microtetraspora viridis subsp. intermedia JCM $3113^{\mathrm{T}}$. The sources of ${ }^{32} \mathrm{P}$-labeled DNA used were A. malachitica $\mathrm{JCM} 3297^{\mathrm{T}}$ (A), Microtetraspora viridis $\mathrm{JCM}$ $3112^{\mathrm{T}}$ (B), strain SF2461 (C), and Microtetraspora viridis subsp. intermedia JCM $3113^{\mathrm{T}}$ (D). Atma., Actinomadura; Mtso., Microtetraspora; Mbso., Microbispora; Atma. verrucoso., Actinomadura verrucosospora; Stmy., Streptomyces.

lerton, Calif.). Hybridization experiments were repeated at least three times.

\section{RESULTS AND DISCUSSION}

DNA homology. The most critical point of the hybridization technique was the DNA preparation (cultivation of microorganisms and extraction and purification of DNAs). Ultraviolet absorption at $260 \mathrm{~nm}$ did not always represent the amount of DNA which was effective for DNA-DNA hybridization. To obtain the correct data for DNA relationships, we repeatedly prepared DNAs and experimented with various combinations of probes and targets. In the reassociation reactions, nylon membranes were found to be better than nitrocellulose membranes in both physical strength and binding efficiency, and the technique proved to be simpler than the S1 nuclease method carried out in liquid phase. From the DNA-DNA hybridization results, the DNA homology values were interpreted as follows: strains showing more than $50 \%$ homology were considered synonymous, and strains showing 15 to $30 \%$ homology were considered different species of the same genus; strains showing less than $10 \%$ homology were assigned to different genera.

Relationship between Microtetraspora viridis and $A$. malachitica. The comparative data for the taxonomic characteristics of strain SF2461, A. malachitica JCM $3297^{\mathrm{T}}$, Microtetraspora viridis $\mathrm{JCM} 3112^{\mathrm{T}}$, and Microtetraspora viridis subsp. intermedia $\mathrm{JCM} 3113^{\mathrm{T}}$ are summarized in Tables 2 through 5. Morphologically, these organisms were very similar to each other, as shown in Fig. 1, except that strains SF2461, JCM $3297^{\mathrm{T}}$, and JCM $3113^{\mathrm{T}}$ had two types of spore chains (four-spore chains and long straight chains) while Microtetraspora viridis JCM $3112^{\mathrm{T}}$ did not (no long spore chains). Nonomura and Ohara (16) proposed the name Microtetraspora viridis subsp. intermedia to emphasize this morphological characteristic. As shown in Fig. 2, the sporebearing characteristics of Microtetraspora viridis differed slightly from those of typical Microtetraspora species ( $\mathrm{Mi}$ crotetraspora glauca, Microtetraspora fusca, and Microtetraspora niveoalba). These species form linear chains of two to four cylindrical (not spherical) spores on aerial hyphae with short sporophores. In cultural properties, strain SF2461 and related strains were characterized by their greenish aerial masses when they were grown on agar media. However, frequent subculturing onto fresh media tended to produce a faded color. In physiology (Table 3), there were some differences among the strains, such as gelatin liquefaction and starch hydrolysis. On the other hand, the sugar utilization patterns were found to be identical. The chemotaxonomic markers of the strains were substantially identical [wall chemotype IIIB, type PI phospholipid, MK-9 $\left(\mathrm{H}_{6}\right)$ as the predominant menaquinone, $16: 0,18: 1$, and $10 \mathrm{Me}-18$ as the major fatty acids, and $72 \mathrm{~mol} \%$ guanine plus cytosine] and were the same as those of the $A$. madurae group (Tables 2 and 5). According to the results of DNA-DNA hybridization experiments (Table 4 and Fig. 3), Microtetraspora viridis JCM $3112^{\mathrm{T}}$ was highly related (96 and $93 \%$ in reverse combination) to Microtetraspora viridis subsp. intermedia JCM $3113^{\mathrm{T}}$ and was also highly related (59 to $71 \%$ ) to strain SF2461 and $A$. malachitica JCM $3297^{\mathrm{T}}$. However, the two type strains of Microtetraspora viridis showed low homology values (6 to $9 \%$ ) with the other type strains of Microtetraspora species. These results indicated that strain SF2461 and related strains should be classified in a single species of Actinomadura sensu stricto. Accordingly, we propose that A. malachitica is a synonym of Microtetraspora viridis and that this taxon should be transferred to the genus Actinomadura as Actinomadura viridis comb. nov., with strain JCM 3112 (= ATCC 27103) as the type strain.

Taxonomic status of the genus Microtetraspora. In 1968 Thiemann et al. (24) established the genus Microtetraspora, whose members were characterized by the formation of linear chains of four spores borne on short sporophores 
TABLE 6. Morphological, cultural, and chemotaxonomic characteristics of type strains of Microtetraspora species $^{a}$

\begin{tabular}{|c|c|c|c|c|c|c|c|c|c|c|c|c|}
\hline \multirow{2}{*}{ Strain } & \multirow{2}{*}{$\begin{array}{l}\text { Color of } \\
\text { aerial } \\
\text { mass }\end{array}$} & \multirow{2}{*}{$\begin{array}{c}\text { Color } \\
\text { of } \\
\text { reverse } \\
\text { side }\end{array}$} & \multirow{2}{*}{$\begin{array}{c}\text { Spore } \\
\text { surfaces }\end{array}$} & \multirow{2}{*}{$\begin{array}{c}\text { No. of } \\
\text { spores } \\
\text { per } \\
\text { chain }\end{array}$} & \multirow{2}{*}{$\begin{array}{l}\text { Wall } \\
\text { chemo- } \\
\text { type }\end{array}$} & \multirow{2}{*}{$\begin{array}{l}\text { Guanine- } \\
\text { plus- } \\
\text { cytosine } \\
\text { content } \\
\text { (mol\%) }\end{array}$} & \multirow{2}{*}{$\begin{array}{l}\text { Phospholipid } \\
\text { type }\end{array}$} & \multicolumn{5}{|c|}{ Menaquinone composition (\%) } \\
\hline & & & & & & & & MK-9 $\left(\mathrm{H}_{0}\right)$ & MK-9 $\left(\mathrm{H}_{2}\right)$ & MK-9 $\left(\mathrm{H}_{4}\right)$ & MK- $9\left(\mathrm{H}_{6}\right)$ & MK-9 $\left(\mathrm{H}_{8}\right)$ \\
\hline $\begin{array}{l}\text { Microtetraspora } \\
\quad \text { glauca JCM } 3300^{\mathrm{T}}\end{array}$ & White $(a)^{b}$ & Green & Smooth & $4(2-3)$ & $\mathrm{IIIB} / \mathrm{C}^{c}$ & 70 & PIV & 12 & 24 & 63 & & \\
\hline $\begin{array}{l}\text { Microtetraspora fusca } \\
\text { ATCC } 23058^{\mathrm{T}}\end{array}$ & White $(\mathrm{a})^{b}$ & Brown & Smooth & $4(2-3)$ & $\mathrm{IIIB} / \mathrm{C}$ & 71 & PIV & 15 & 23 & 60 & & \\
\hline $\begin{array}{l}\text { Microtetraspora } \\
\text { niveoalba } \mathrm{JCM} \\
3149^{\mathrm{T}}\end{array}$ & White (a) & None & Smooth & $4(2-3)$ & $\mathrm{IIIB} / \mathrm{C}$ & 71 & PIV & 11 & 21 & 67 & & \\
\hline $\begin{array}{l}\text { Microtetraspora viridis } \\
\text { JCM } 3112^{\mathrm{T}}\end{array}$ & $\begin{array}{l}\text { Green } \\
(24 \mathrm{ec})\end{array}$ & None & Smooth & $4(3-6)$ & IIIB & 72 & PI & & 1 & 12 & 60 & 27 \\
\hline
\end{tabular}

arising from the aerial hyphae at a $45^{\circ}$ angle. These authors proposed two species, Microtetraspora glauca (type species) and Microtetraspora fusca, and reported that their strains had a new cell wall chemotype; however, this was later corrected to wall chemotype III by Nonomura and Ohara (17). In 1971 Nonomura and Ohara (16) proposed the name Microtetraspora viridis for organisms forming greenish aerial masses. These authors stated that this species bears a close resemblance to the Nocardia (Actinomadura) madurae group in its cell wall composition. Later, in 1971, they described the new taxon Microtetraspora niveoalba (17). In 1980 Tomita et al. (25) proposed a new name, "Microtetraspora caesia," for organisms which were characterized by secondary branches from the short spore chains borne downward at an angle of ca. $45^{\circ}$, formation of zoospores, and cell walls containing meso-diaminopimelic acid and galactose but lacking arabinose and madurose. However, this name does not appear on the Approved Lists (22). There are now four valid species (see above) in the genus Microtetraspora. The taxonomic data for the type strains of Microtetraspora species and related strains are summarized in Tables 5 through 7. The chemotaxonomic markers for Microtetraspora glauca $\mathrm{JCM} 3300^{\mathrm{T}}$, Microtetraspora fusca ATCC $23058^{\mathrm{T}}$, and Microtetraspora niveoalba JCM $3149^{\mathrm{T}}$ were almost identical [wall chemotype IIIB/C, type PIV phospholipid, MK- $9\left(\mathrm{H}_{4}\right)$ as the predominant menaquinone, iso-16 and $10 \mathrm{Me}-17$ as the major fatty acids, and 70 to $71 \mathrm{~mol} \%$ guanine plus cytosine]. DNA homology values (28 and 37\%) showed that these three type strains are related to one another. Based on chemotaxonomy and DNA homology results, these organisms clearly differed from Microtetraspora viridis, but resembled the $A$. pusilla group. These results are in good agreement with those of Poschner et al. (19). As shown in Table 7, it is interesting that these three strains of Microtetraspora spp. are more highly related to Microbispora rosea and Streptosporangium roseum (homology values of 13 to $20 \%$ ) than to Microtetraspora viridis and $A$. citrea (8 to $10 \%$ ). "Microtetraspora caesia" ATCC $31295^{\mathrm{T}}$ exhibited low homology values (6 to $10 \%$ ) with all of the other Microtetraspora species as determined by DNADNA hybridization. This organism was also clearly different from the other Microtetraspora species based on chemotaxonomy. For example, a determination of the menaquinone composition of "Microtetraspora caesia" revealed $68 \%$ MK-10 $\left(\mathrm{H}_{4}\right)$ and $26 \% \mathrm{MK}-9\left(\mathrm{H}_{4}\right)$, with other minor components.

Chemotaxonomic and hybridization techniques are more reliable methods than spore chain morphology (whether the chains are composed of two spores, four spores, or more) for the classification of sporoactinomycetes with wall chemotype III. Moreover, as shown in Fig. 1 and 2, the morphological characteristics prescribing the genus Microtetraspora are not suitable criteria for the separation of the genus from Actinomadura. Accordingly, the Microtetraspora species

TABLE 7. DNA homologies of Microtetraspora species and related strains

\begin{tabular}{|c|c|c|c|c|}
\hline \multirow[b]{2}{*}{ Source of unlabeled DNA } & \multicolumn{4}{|c|}{$\%$ Hybridization with ${ }^{32} \mathrm{P}$-labeled DNA from: } \\
\hline & $\begin{array}{c}\text { Microtetraspora } \\
\text { glauca } \\
\text { JCM } 3300^{\mathrm{T}}\end{array}$ & $\begin{array}{c}\text { Microtetraspora } \\
\text { fusca } \\
\text { ATCC } 23058^{\mathrm{T}}\end{array}$ & $\begin{array}{l}\text { Microtetraspora } \\
\text { niveoalba } \\
\text { JCM } 3149^{\mathrm{T}}\end{array}$ & $\begin{array}{l}\text { "Microtetraspora } \\
\text { caesia" } \\
\text { ATCC } 31295^{\mathrm{T}}\end{array}$ \\
\hline Microtetraspora glauca $\mathrm{JCM} 3300^{\mathrm{T}}$ & 100 & 31 & 28 & 6 \\
\hline Microtetraspora fusca ATCC $23058^{\mathrm{T}}$ & 30 & 100 & 37 & 7 \\
\hline Microtetraspora niveoalba JCM $3149^{\mathrm{T}}$ & 32 & 36 & 100 & 7 \\
\hline Actinomadura ferruginea $\mathrm{JCM} 3283^{\mathrm{T}}$ & 21 & 15 & 17 & 7 \\
\hline Actinomadura helvata JCM $3143^{\mathrm{T}}$ & 15 & 21 & 19 & 7 \\
\hline Actinomadura pusilla ATCC $27296^{\mathrm{T}}$ & 15 & 18 & 18 & 8 \\
\hline Microbispora rosea $\mathrm{JCM} 3006^{\mathrm{T}}$ & 18 & 20 & 16 & 6 \\
\hline Streptosporangium roseum IFO $3776^{\mathrm{T}}$ & 13 & 17 & 15 & 7 \\
\hline "Microtetraspora caesia" ATCC $31295^{\mathrm{T}}$ & 8 & 8 & 7 & 100 \\
\hline Microtetraspora viridis $\mathrm{JCM} 3112^{\mathrm{T}}$ & 9 & 8 & 9 & 10 \\
\hline Actinomadura citrea ATCC $27887^{\mathrm{T}}$ & 10 & 8 & 9 & 12 \\
\hline Streptomyces griseus IFO $12875^{\mathbf{T}}$ & 7 & 7 & 6 & 8 \\
\hline
\end{tabular}


except "Microtetraspora caesia" should be combined with the genus Actinomadura, which is, however, heterogeneous itself.

\section{ADDENDUM IN PROOF}

Recently, Goodfellow et al. (M. Goodfellow, E. Stackebrandt, and R. M. Kroppenstedt, p. 233-238, in Y. Okami, T. Beppu, and H. Ogawara [ed.], Biology of actinomycetes ' 88,1988 ) proposed a new genus, "Nonomuria," members of which are sporoactinomycetes belonging to the family Streptosporangiaceae and are characterized by the following chemical markers: wall chemotype, IIIB; type PIV phospholipid; MK-9 $\left(\mathrm{H}_{4}\right)$ as the predominant menaquinone; $10 \mathrm{Me}-17$ as the major fatty acid; and 64 to $69 \mathrm{~mol} \% \mathrm{G}+\mathrm{C}$. They also proposed the transfer of Actinomadura pusilla and allied species to the new genus. Our results indicate that Microtetraspora, with the exception of Microtetraspora viridis and "Microtetraspora caesia," and the new genus might be united into one genus.

\section{ACKNOWLEDGMENTS}

We are grateful to S. Hoshiko of the Karolinska Institutet, Stockholm, Sweden, T. Kudo of the Japan Collection of Microorganisms, Saitama, Japan, and C. J. Thompson of the Institut Pasteur, Paris, France, for their kind suggestions on the DNA work. We thank L. Lockett and E. Takano for preparing the manuscript.

\section{LITERATURE CITED}

1. Athalye, M., M. Goodfellow, J. Lacey, and R. P. White. 1985. Numerical classification of Actinomadura and Nocardiopsis. Int. J. Syst. Bacteriol. 35:86-98.

2. Becker, B., M. P. Lechevalier, and H. Lechevalier. 1965. Chemical composition of cell-wall preparations from strains of various form-genera of aerobic actinomycetes. Appl. Microbiol. 13: 236-243.

3. Collins, M. D., H. N. Shah, and D. E. Minnikin. 1980. A note on the separation of natural mixtures of bacterial menaquinones using reverse-phase thin-layer chromatography. J. Appl. Bacteriol. 48:277-282.

4. Fischer, A., R. M. Kroppenstedt, and E. Stackebrandt. 1983. Molecular genetic and chemotaxonomic studies on Actinomadura and Nocardiopsis. J. Gen. Microbiol. 129:3433-3446.

5. Goodfellow, M., and T. Cross. 1984. Classification, p. 7-164. In M. Goodfellow, M. Mordarski, and S. T. Williams (ed.), The biology of actinomycetes. Academic Press, Inc. (London), Ltd., London.

6. Hopwood, D. A., M. J. Bibb, K. F. Chater, T. Kieser, C. J. Bruton, H. M. Kieser, D. J. Lydiate, C. P. Smith, J. M. Ward, and H. Schrempf. 1985. Genetic manipulation of Streptomyces, a laboratory manual. The John Innes Foundation, Norwich, England.

7. Jacobson, E., W. C. Grauville, and C. E. Fogs. 1958. Color harmony manual, 4th ed. Container Corporation of America, Chicago.

8. Lavrova, N. V., T. P. Preobrazehenskaya, and M. A. Sveshnikova. 1972. Isolation of soil actinomycetes on selective media with rubomycin. Antibiotiki (Mosc.) 17:965-970.

9. Lechevalier, M. P. 1968. Identification of aerobic actinomycetes of clinical importance. J. Lab. Clin. Med. 71:934-944.
10. Lechevalier, M. P., C. DeBièvre, and H. Lechevalier. 1977. Chemotaxonomy of aerobic actinomycetes: phospholipid composition. Biochem. Syst. Ecol. 5:249-260.

11. Lechevalier, M. P., A. E. Stern, and H. A. Lechevalier. 1981. Phospholipids in the taxonomy of actinomycetes. Zentralbl. Bakteriol. Parasitenkd. Infektionskr. Hyg. Abt. 1 Suppl. 11: 111-116.

12. Marmur, J., and P. Doty. 1962. Determination of the base composition of deoxyribonucleic acid from its thermal denaturation temperature. J. Mol. Biol. 5:109-118.

13. Miyadoh, S., S. Amano, H. Tohyama, and T. Shomura. 1987. Actinomadura atramentaria, a new species of Actinomycetales. Int. J. Syst. Bacteriol. 37:342-346.

14. Miyadoh, S., H. Tohyama, S. Amano, T. Shomura, and T. Niida. 1985. Microbispora viridis, a new species of Actinomycetales. Int. J. Syst. Bacteriol. 35:281-284.

15. Nonomura, H., and Y. Ohara. 1969. Distribution of actinomycetes in soil. VI. A culture method effective for both preferential isolation and enumeration of Microbispora and Streptosporangium strains in soil (part I). J. Ferment. Technol. 47: 463-469.

16. Nonomura, H., and Y. Ohara. 1971. Distribution of actinomycetes in soil. VIII. Green-spore group of Microtetraspora, its preferential isolation and taxonomic characteristics. J. Ferment. Technol. 49:1-7.

17. Nonomura, H., and Y. Ohara. 1971. Distribution of actinomycetes in soil. IX. New species of genera Microbispora and Microtetraspora, and their isolation method. J. Ferment. Technol. 49:887-894.

18. Okami, Y., H. Hamada, and N. Ueda. 1970. Relationship between genera of actinomycetes with reference to gas chromatographic analysis, p. 457-475. In H. lizuka and T. Hasegawa (ed.), Proceedings of the 1st International Conference on Culture Collections. University of Tokyo Press, Tokyo.

19. Poschner, J., R. M. Kroppenstedt, A. Fischer, and E. Stackebrandt. 1985. DNA-DNA reassociation and chemotaxonomic studies on Actinomadura, Microbispora, Microtetraspora, Micropolyspora and Nocardiopsis. Syst. Appl. Microbiol. 6:264 270 .

20. Rogosa, M., C. A. Walczak, J. M. Walat, D. Mcvey, and M. I. Krichevsky. 1986. Codes and abbreviations for approved or effectively published names of genera of bacteria published from January 1980 to October 1985 and of generally recognized yeast genera. Int. J. Syst. Bacteriol, 36:464-472.

21. Shirling, E. B, and D. Gottlieb. 1966. Method for characterization of Streptomyces species. Int. J. Syst. Bacteriol. 16:313340 .

22. Skerman, V. B. D., V. McGowan, and P. H. A. Sneath (ed.). 1980. Approved lists of bacterial names. Int. J. Syst. Bacteriol. 30:225-420.

23. Tamaoka, J., Y. Katayama-Fujimura, and H. Kuraishi. 1983. Analysis of bacterial menaquinone mixtures by high performance liquid chromatography. J. Appl. Bacteriol. 54:31-36.

24. Thiemann, J. E., H. Pagani, and G. Beretta. 1968. A new genus of the Actinomycetales: Microtetraspora gen. nov. J. Gen. Microbiol. 50:295-303.

25. Tomita, K., Y. Hoshino, T. Sasahira, K. Hasegawa, M. Akiyama, H. Tsukiura, and H. Kawaguchi. 1980. Taxonomy of the antibiotic Bu-2313 producing organism, Microtetraspora caecia sp. nov. J. Antibiot. 33:1491-1501.

26. Waksman, S. A. 1961. The actinomycetes, vol. 2. Classification, identification and descriptions of genera and species. The Williams \& Wilkins Co., Baltimore. 